\title{
Sustainability for Management and Protection Tin Mining Environment
}

\author{
Fitri Ramdhani Harahap ${ }^{1,1}$, Ridha Taqwa ${ }^{2}$, Restu Juniah $^{3}$, and Elisa Wildayana ${ }^{4}$ \\ ${ }^{1}$ Department of Environmental Science, Postgraduate Program, Universitas Sriwijaya, 30139, \\ Palembang, Indonesia \\ ${ }^{2}$ Department of Sociology, Graduate Program, Universitas Sriwijaya, 30139, Palembang, Indonesia \\ ${ }^{3}$ Department of Mining, Graduate Program, Universitas Sriwijaya, 30139, Palembang, Indonesia \\ ${ }^{4}$ Department of Agribusiness, Faculty of Agriculture, Universitas Sriwijaya, 30139, Palembang, \\ Indonesia
}

\begin{abstract}
Tin mining environment sustainability is an effort for the protection and management of the environment as a systematic and integrated include planning, utilization, control, maintenance, surveillance, and enforcement of the law. This effort was done as big as for the prosperity of the people. Development in the field of natural resources and the environment is an attempt to harness the natural resources for the prosperity of most of the people by remaining attentive to the preservation of the function and the balance of the environment, economic interests the local society and culture, as well as spatial harmony in effort attainment of sustainable development. The environment has supported limited environmental resources like tin mine. During the exploitation is done are not beyond the limits of resources support neighborhood then natural resources can be used sustainably in accordance carrying capacity, i.e. the ability of natural resources to support the life of all beings in the ecosystem on an ongoing basis.
\end{abstract}

\section{Introduction}

The term Sustainable Development or sustainable development is also called, is designed to transform the conventional development paradigm (for conventional development) into a better direction. Broadly speaking, the definition of sustainable development is defined as development that adheres to the principle of the fulfillment of the needs of today without compromising the interests of generations to come[1]. But, in fact, sustainable development is not only based on environmental issues but instead undertook to include the policy in the field of economic, social and environmental protection. When referring to the results of the meeting of the World Summit in New York in 2005, these three policies that have been mentioned above have an affinity with each other, besides that, the third pillar of the above is also a catalyst for the achievement of sustainable development[2]. In other words, with the creation of synergies between economic, social

\footnotetext{
*Corresponding author: author@email.org
} 
policy and the protection of the environment, it will be created a controlled relationship (bearable), equitable, and the relationship that has a spirit of development, the achievement of synergies between these dimensions will create development that is sustainable or sustain[3]. Through this sustainable development, due to the negative impact of development with conventional methods in the form of environmental damage through the destruction of natural resources such as water, forests, as well as the massive exploitation the resulting mining damage Ecology, can be prevented.

The availability of natural resources in improving the development was very limited and uneven, while natural resource demand continues to increase, due to increased development to meet the needs of the population. The efforts of controlling the pollution and environmental damage, then, need to do development planning which is based on the principle of sustainable development. The principle of sustainable development is done by combining the capabilities of the environment, natural resources and technology into the development process to ensure this generation and future generations.

\section{Results and Discussions}

\subsection{Tin Mining in Indonesia}

Mining is one of the important sectors in the economy of Indonesia, especially in his role as a foreign exchange earner. The mining sector is composed of sub-sectors of the oil and gas, General mining and minerals C. Tin mining is one of the sub-sectors General mining has been done since the reign of the Netherlands East Indies in the 17th century to now [4] and is one of the sectors of the economy, the mainstay of Bangka Belitung Islands province. Development that is based on the extraction of natural resources such as mining of tin will ultimately be stalled when the lead reserves run out. According to the US Geological Survey year 2006, the measured reserves of Tin in Indonesia around 800.000 to 900.000 tons, of which the islands of Bangka Belitung is a major producer of Tin. The average production level of about 60.000 tons/year, or the equivalent of 90.000 tons/year of lead sand. According to the Industrial Technology Research Institute (ITRI), PT Timah Tbk (TINS) managed to record the performance is good enough where this achievement is measured from lead production tonnage results. It is characterized by the inclusion of large TINS in 10 best years of refined Tin produced 2017.

Table 1. World Tin Producers 2017

\begin{tabular}{|c|c|}
\hline Produsen (Country) & Production (tons/year) \\
\hline Yunnan Tun (China) & 74.500 \\
\hline PT Timah (Indonesia) & 30.200 \\
\hline Malaysia Smelting Corp (Malaysia) & 27.200 \\
\hline Yunnan Chengfeng (China) & 26.800 \\
\hline Minsur (Peru) & 18.000 \\
\hline EM Vinto (Bolivia) & 12.600 \\
\hline Guangxi China Tin (China) & 11.500 \\
\hline Thaisarco (Thailand) & 10.600 \\
\hline Metallo (Belgium) & 9.700 \\
\hline Gejiu Zi-Li (China) & 8.700 \\
\hline
\end{tabular}

Source :[5]

In the fifties, tin had been the result of the second mining commodity after oil, which contributes to the revenue of the State. Although history tin mining has been going on for 
more than two hundred years, the potential lead resources still remain unanswered. The tin mining business ranging from exploration activities to ongoing, intensive marketing, even though the business activities have been lasting quite a long time in Indonesia. Tin mining activity still requires exploration for the discovery of new reserves, particularly offshore deposits. Resources and reserves that have been revealed have not represented the overall offshore deposits particularly located at a depth of more than 50 meters, as well as the potential for low levels with respect to price increases, become high potentially economic.

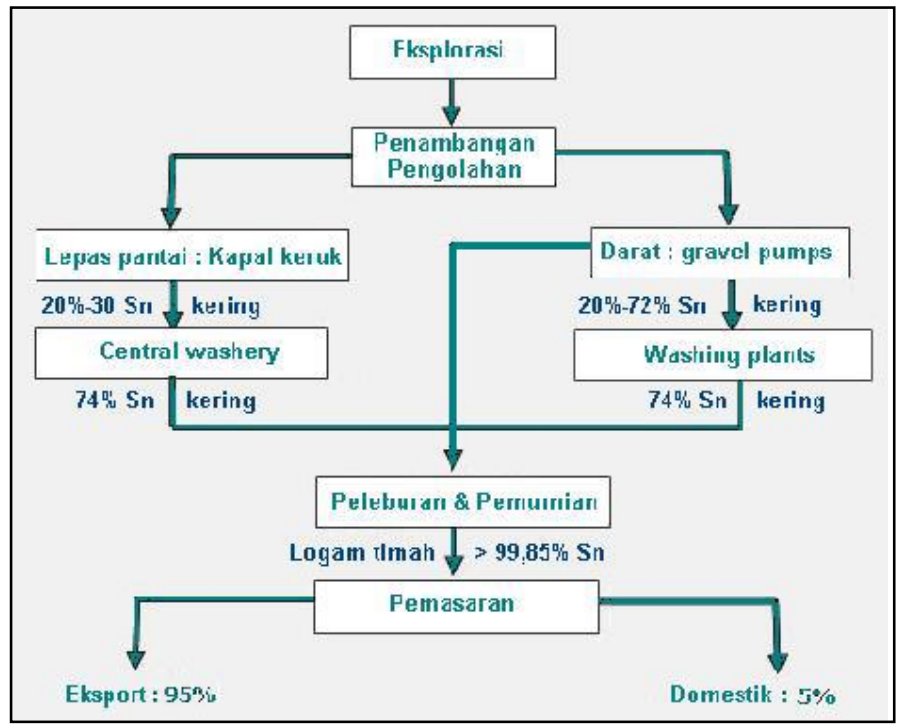

Fig. 1. Flow chart of the tin mining business activities of PT. Timah Tbk

Indonesia as the world's largest tin exporter has the opportunity to maintain or control the price of tin in the world market. This needs to be managed optimally to keep and protect the mining business activities in order to produce a contribution to a more optimal development.

\subsection{Enviroment Management and Protection}

Management used in minimizing the degradation of land, water, and vegetation through the use of early rehabilitation (restoration) and to other (reclamation), as well as the socialeconomic interests through planning, organizing, coordination, and controlling the tin resources which is carried out jointly with stakeholders. The term has been described as a general process of reclamation where the surface of the land recovered for allocation to another. Reclaiming is based on the principles of ecological recovery and integrated is called restoration. The restoration of the environment is basically intended to return towards the original ecosystem aspects of structure and function. Rehabilitation is the term used for the process ahead of the return to the original ecosystem, ecosystem by creating alternative towards the original ecosystem through replacement.

In the regulation of Government of the Republic of Indonesia, Number 78 of 2010 about reclamation and post mine principles of protection and environmental management of mining include: 
1. Protection of the quality of surface water, ground water, sea water, air, and soil, as well as on the basis of the standard quality raw or raw damage criteria of the environment in accordance with the provisions of regulation ;

2. Protection and restoration of biodiversity;

3. Guarantee against stability and security a heap of rocks and tailings pond, cover, landmines, and other man-made structures;

4. Utilization of landmines in accordance with the allocation;

5. Pay attention to the social values and local cultures; and

6. Protection against the quantity of groundwater in accordance with the provisions of the legislation.

\subsection{Tin Mining Environment Sustainability}

The mining sector is one of the sectors of economic activity in addition to its activities producing the production results of the mines, also raises the impact of land use and landscape damage which is difficult to be returned to its original form. The existence of the concept of green mining is expected to create a balanced relationship between the company, the mining community, and offender nature. Nevertheless, it is very difficult to make a choice between the exploitation of resources and the protection of the ecological environment[6].

Forms management of tin mining and environmental protection has been done can be seen from mining activities conducted by PT Timah in its annual report, namely through environmental policy by obeying all regulations and legislation covering related environmental management related to the company's business. As proof of the seriousness of the company in maintaining the balance of the environment, PT Timah has gained several certificates.

Table 2. List of Proper Certification gained by PT TIMAH Tbk in 2017

\begin{tabular}{|c|c|c|c|}
\hline Received By & $\begin{array}{c}\text { Type of } \\
\text { Certification }\end{array}$ & $\begin{array}{c}\text { Institution Issuing } \\
\text { Certification }\end{array}$ & Valide Date \\
\hline $\begin{array}{c}\text { PT TIMAH (Persero) Tbk - } \\
\text { Unit Metalurgi Mentok }\end{array}$ & ISO 14001:2004 & PT. SGS Indonesia & $2015-2018$ \\
\hline $\begin{array}{c}\text { PT Dok \& Perkapalan Air } \\
\text { Kantung }\end{array}$ & ISO 14001:2004 & PT. SGS Indonesia & $2015-2018$ \\
\hline
\end{tabular}

Source : Annual Report (2017)

In addition, PT Timah has also shown its commitment by setting up environmental management costs and post mine for environmental management and monitoring activities of the amount set in accordance the standards of financial accounting. The Company has allocated budget for Environmental management and monitoring activities of which the amount is determined as provision per weight unit of refined tin produced. The provision for environmental rehabilitation based on Law No. 32/2009 regarding Conservation and Environmental management, GR 78 regarding the Reclamation and Post Mining, and MoEMR No. 7/2014 regarding Reclamation and Mining Closure Activity for Mineral and Coal Mine Business.

Refers to Act No. 40 of the year 2007 about limited liability company, social responsibility and The environment is the company's commitment to a role as well as in sustainable economic development in order to improve the quality of life and the environment useful, both for the company itself, the community local, as well as society in General. Targets and plans of CSR activities on the community, each year is always 
adapted to the impact happened. In the year 2017, the company has set a work plan Social responsibility towards the development of social and the majority of the affected community at the company's business operations. Impact of who wants to be given The company to the community include the impact that includes aspects like chances of trying and work, income and adequate for the welfare of the community, health worker/community etc.

Table 3. List of Proper Certification Gained by PT TIMAH Tbk in 2017

\begin{tabular}{|c|c|}
\hline Program & Value (IDR) \\
\hline Waste Management, Emission, and Remediation & $\mathrm{Rp} \mathrm{3.003.614.949}$ \\
\hline Waste Management & $\mathrm{Rp} 1.207 .656 .875$ \\
\hline Emission and Air Quality Controlling & $\mathrm{Rp} 72.800 .000$ \\
\hline Licensing of Environmental Protection and Management & $\mathrm{Rp} 766.539 .058$ \\
\hline Environmental Development & $\mathrm{Rp} 933.217 .600$ \\
\hline Equipment expenditure, maintenance, operational & $\mathrm{Rp} 1.520 .580 .334$ \\
\hline Control of Water waste quality and sea water & $\mathrm{Rp} \mathrm{382.774.200}$ \\
\hline Prevention Cost and Environmental Man & $\mathrm{Rp} 185.082 .473$ \\
\hline Environmental education and training & $\mathrm{Rp} \mathrm{3.281.135.000}$ \\
\hline $\begin{array}{c}\text { Reporting and Documentation of RKL-RPL \& B3 Waste } \\
\text { Program }\end{array}$ & $\mathrm{Rp} 802.865 .300$ \\
\hline Environmental Document Consultant & $\mathrm{Rp} \mathbf{2 . 1 5 6 . 2 6 5 . 7 8 9}$ \\
\hline External Environmental Audit
\end{tabular}

Source : Annual Report (2017)

The sustainability of the company's business depends not only on financial performance but also environmental sustainability and the ability to give added value to the local community. Because of the then, the company has always strived to operate a business environmentally friendly and sustainable. Benchmark sustainable business success is ranked Program Assessment Rating of the company's performance in the Environmental Management (Proper). In 2017, PT TIMAH Tbk has reached the setting Proper targets adjusted for previous year's accomplishments and the level of performance of the subsidiaries in the field of the environment.

Refering to Law Number 40 year 2007 about limited liability company, social responsibility and The environment is the company's commitment to a role as well as in sustainable economic development in order to improve the quality of life and the environment useful, both for the company itself, the community local, as well as society in General. Some of the activities that have been carried out by the company during the the year 2017, among others: help victims of natural disasters, education or training assistance, help increase health, help the development of the means or public facilities, help with the means of worship, help the preservation of the natural as well as social assistance community in order poverty reduction. As a form of corporate responsibility towards the environment has been explored, the company has performed an action reclamation of the former mining location gradually. The company has a reclamation program made during the five year 2015-2019. In the year 2017, The company has been conducting the reclamation of the former exploration mine is as follows: 
Table 4. Reclamation of the former exploration mine in 2017

\begin{tabular}{|c|c|c|}
\hline $\begin{array}{c}\text { Mining Business } \\
\text { License Area }\end{array}$ & $\begin{array}{c}\text { Breadth of 2015-2019 } \\
\text { Reclamation Plan (Ha) }\end{array}$ & $\begin{array}{c}\text { Realization of Reclamation per } \\
\mathbf{2 0 1 7} \text { (Ha) }\end{array}$ \\
\hline Bangka & 344 & 158.81 \\
\hline West Bangka & 226 & 109.18 \\
\hline Central Bangka & 201 & 63.42 \\
\hline South Bangka & 157 & 52.05 \\
\hline Belitung & 155 & 39.91 \\
\hline East Belitung & 402 & 125.37 \\
\hline Cross District & 541 & 68.97 \\
\hline Total & $\mathbf{2 . 0 2 7}$ & $\mathbf{6 8 8 . 7 1}$ \\
\hline
\end{tabular}

Source : Annual Report (2017)

\section{Conclusion}

Tin mining can be done in order to economically benefit the State, employers and the community; social giving progress for society through the enhancement of human resources, health and social harmony; and in the environment can be maintained and properly managed not only to the current generation but also for generations to come.

\section{References}

1. Usman, Dudi Nasrudin, Sri Widayati, Siyanti, dan Linda Pulungan. Ethos 5, 1 (2017)

2. Australian Government Departement of Industry, Innovation and science (A Guide to Leading Practice Sustainable Development in Mining, Departement of Industry, Innovation and Science, Canberra, 2011)

3. Putuhena, Jusmy Dolvis. Model Dinamik Pengelolaan Daerah Aliran Sungai (Watershed) Dalam Upaya Penyediaan Air yang Berkelanjutan di Semenanjung Meitimor Pulau Ambon. Disertasi, Sekolah Pascasarjana Institut Pertanian Bogor, Bogor (2013)

4. Sujitno, Sutedjo. Sejarah penambangan timah di indonesia abad ke-18 - abad ke-19 (PT. Timah (Persero) Tbk, Pangkal pinang, 2007)

5. Kontan.co.id. Produksi PT Timah terbesar kedua dunia. 2018. (diakses 11 September 2018) PT Timah Tbk. Laporan Tahunan. Pangkalpinang: PT. Timah Tbk (2017)

6. Sari, Dian Permata, dan Imam Buchori. Jurnal Pembangunan Wilayah \& Kota 11, 3 (2015) 